\title{
Subclinical herpesvirus infection in farmed turbot Scophthalmus maximus
}

\author{
H. Hellberg ${ }^{1, *}$, E. O. Koppang ${ }^{2}$, B. Tørud ${ }^{3}$, I. Bjerkås ${ }^{2}$ \\ ${ }^{1}$ National Veterinary Institute Bergen, PO Box 1263 Sentrum, 5811 Bergen, Norway \\ ${ }^{2}$ Department of Morphology, Genetics and Aquatic Biology, Norwegian School of Veterinary Science, PO Box 8146 Dep., \\ 0033 Oslo, Norway \\ ${ }^{3}$ Veterinærtjenesten for fiskoppdrett i Hemme, Halsa, Aure og Snillfjord (VHHAS), 6687 Valsøyfjord, Norway
}

\begin{abstract}
Subclinical infections with a herpesvirus were detected by light and electron microscopic examination of juvenile turbot collected during a national surveillance programme. Virions detected in the epidermis of skin and in the epithelium of gills had a morphology consistent with those of Herpesvirus scophthalmi described from turbot in the United Kingdom and Denmark. This is the first report of herpesvirus infection in turbot in Norway.
\end{abstract}

KEY WORDS: Herpesvirus · Subclinical infection · Scophthalmus maximus

\section{INTRODUCTION}

Members of the family Herpesviridae are enveloped double-stranded DNA viruses with an icosahedral capsid structure. Transcription and replication of virus is located in the nucleus of infected cells. Viral DNA is subsequently inserted into preformed capsids, and the capsid obtains its envelope by budding through the nuclear membrane. Virus particles accumulate in cytoplasmic vacuoles, from which they are then released (Roizman 1982). Infections with herpesviruses are not uncommon in aquatic organisms (Wolf 1988, Hedrick \& Sano 1989, Hetrick \& Hedrick 1993, Håstein 1999), including turbot Scophthalmus maximus, where a herpesvirus originally designated as Herpesvirus scophthalmi has been described. This herpesvirus was detected among juvenile turbot in the United Kingdom (Buchanan \& Madely 1978) and in Denmark (Bloch \& Larsen 1994). In both reports, the affected fish showed clinical signs including lethargy and anorexia, and in the Danish case severe general oedema, ascites and in some cases rectal prolapse. In the present paper, the findings of herpesvirus particles in the gills and skin of

*E-mail: hege.hellberg@vetinst.no turbot were the result of a surveillance and control programme. Mortality or signs of clinical manifestations of disease were not observed.

Farming of marine fish species is a developing industry in Norway, and viral diseases may be a major threat to a successful production of larvae and juveniles. As herpesvirus infections on several occasions have caused severe mortality in farmed turbot, a national surveillance programme was established to get an overview of the distribution of Herpesvirus scophthalmi in farmed turbot in Norway. The results from the surveillance programme will serve as a basis for further control measures.

\section{MATERIALS AND METHODS}

Fish. Infected fish were sampled from a population of 50000 juvenile turbot, hatched in June 2000 in France. The entire population originated from the same batch of eggs, and were kept in seawater with a salinity of 29 to $33 \mathrm{ppt}$ and a water temperature of $14^{\circ} \mathrm{C}$ prior to transport. The fish were bath-vaccinated with AquaVac $^{\mathrm{TM}}$ Vibrio (Aqua Culture Vaccines) against vibriosis (Vibrio anguillarum) at $85 \mathrm{~d}$ post-hatching, and revaccinated orally with AquaVac ${ }^{\mathrm{TM}}$ Vibrio Oral for $3 \mathrm{~d}$ start- 
ing $122 \mathrm{~d}$ post-hatching. In addition, the fish were treated with formaldehyde in a final concentration of $0.09 \mathrm{~g} \mathrm{l}^{-1}$ water for 20 to $30 \mathrm{~min}$ at $14^{\circ} \mathrm{C}$ shortly before being exported to Norway.

The fish were transported by car in twelve $1.8 \mathrm{~m}^{3}$ tanks at a density of $41 \mathrm{~kg} \mathrm{tank}^{-1}$. The juveniles had a mean weight of $9.8 \mathrm{~g}$. Water temperature was $12^{\circ} \mathrm{C}$ at departure and $13^{\circ} \mathrm{C}$ at arrival $44 \mathrm{~h}$ later.

At arrival in Norway, $137 \mathrm{~d}$ post-hatching, the fish were put in 3 raceways of $12 \times 2 \mathrm{~m}^{2}$. Seawater was supplied from $80 \mathrm{~m}$ depth at a rate of $200 \mathrm{l} \mathrm{min}^{-1}$ and water temperature fluctuated between $12^{\circ}$ and $15^{\circ} \mathrm{C}$. The fish were fed with 2 and $3 \mathrm{~mm}$ Danafeed turbot feed (Danafeed), at a rate of $10 \mathrm{~g} \mathrm{~kg}^{-1} \mathrm{~d}^{-1}$. The raceways were supposedly self-cleaning, but faeces and surplus feed accumulated during the first 3 to $4 \mathrm{wk}$ before suitable cleaning routines were established. The hygienic problems during the first $4 \mathrm{wk}$ period did not appear to affect the fish negatively. During the first weak after transport, a total of 11 turbot died.

Sampling. The fish were sampled twice, 5 and $40 \mathrm{~d}$ after importation. Thirty individuals were selected at random and sacrificed with an overdose of anaesthetic (Metakain powder diluted to a concentration exceeding $0.2 \mathrm{~g} \mathrm{l}^{-1}$, Norsk medisinaldepot). At the first sampling, the fish were decapitated, and the heads fixed in $10 \%$ neutral buffered formalin for at least $48 \mathrm{~h}$ for light microscopy. Subsequently material was embedded in paraffin using standard procedures. Sections were cut $(4 \mu \mathrm{m})$, mounted on glass slides and stained with haematoxylin and eosin ( $\mathrm{H} \& \mathrm{E}$ ) according to standard procedures (Bancroft \& Stevens 1990).

At the second sampling, specimens from skin (dorsal side) and gills from each fish were fixed in $2.5 \%$ glutaraldehyde in $0.5 \mathrm{M}$ cacodylate buffer for transmission electron microscopy and in 10\% neutral buffered formalin for light microscopy. The glutaraldehyde-fixed material was transported on ice to the electron microscopy laboratory and postfixed in $2 \% \mathrm{OsO}_{4}$ in $0.1 \mathrm{M}$ cacodylate buffer, $\mathrm{pH} 7.2$ for $2 \mathrm{~h}$, dehydrated in ascending concentrations of ethanol and embedded in LX 112 Resin (Ladd Research Industries). Semi-thin (1 $\mu \mathrm{m})$ sections were mounted on glass slides and stained with toluidine blue. Ultra-thin sections were mounted on copper grids, stained with uranyl acetate and lead citrate, and examined in a Philips 208S electron microscope.

\section{RESULTS}

\section{Light microscopy results}

Giant cells were observed in the epidermis and/or gills in sections of the sampled fish (Table 1). The giant
Table 1. Scophthalmus maximus. Prevalence of giant cells in histological sections of gills and epidermis of turbot. $\mathrm{N}=$ number of fish examined

\begin{tabular}{|ccccc|}
\hline $\begin{array}{c}\text { Sampling } \\
\text { no. }\end{array}$ & $\mathrm{N}$ & Epidermis & Gill & $\begin{array}{c}\text { Epidermis } \\
\text { and gill }\end{array}$ \\
\hline 1 & 28 & 26 & 13 & 13 \\
2 & 30 & 15 & 9 & 9 \\
\hline
\end{tabular}

cells were generally rounded, but showed considerable variation in size, the largest being around $80 \mu \mathrm{m}$ in diameter. The centrally or eccentrically located nucleus was usually rounded, but a more irregular shape occurred occasionally. The cytoplasm stained basophilic and appeared granular, while the nuclei of the giant cells usually stained more strongly basophilic and appeared less granular in structure. This was occasionally reversed, with the nucleus appearing eosinophilic. Both types of nuclear staining could be observed in the same sections and in the same tissue. In some cells, there was a distinct division between the nucleus and the cytoplasm, whereas in other cells, this

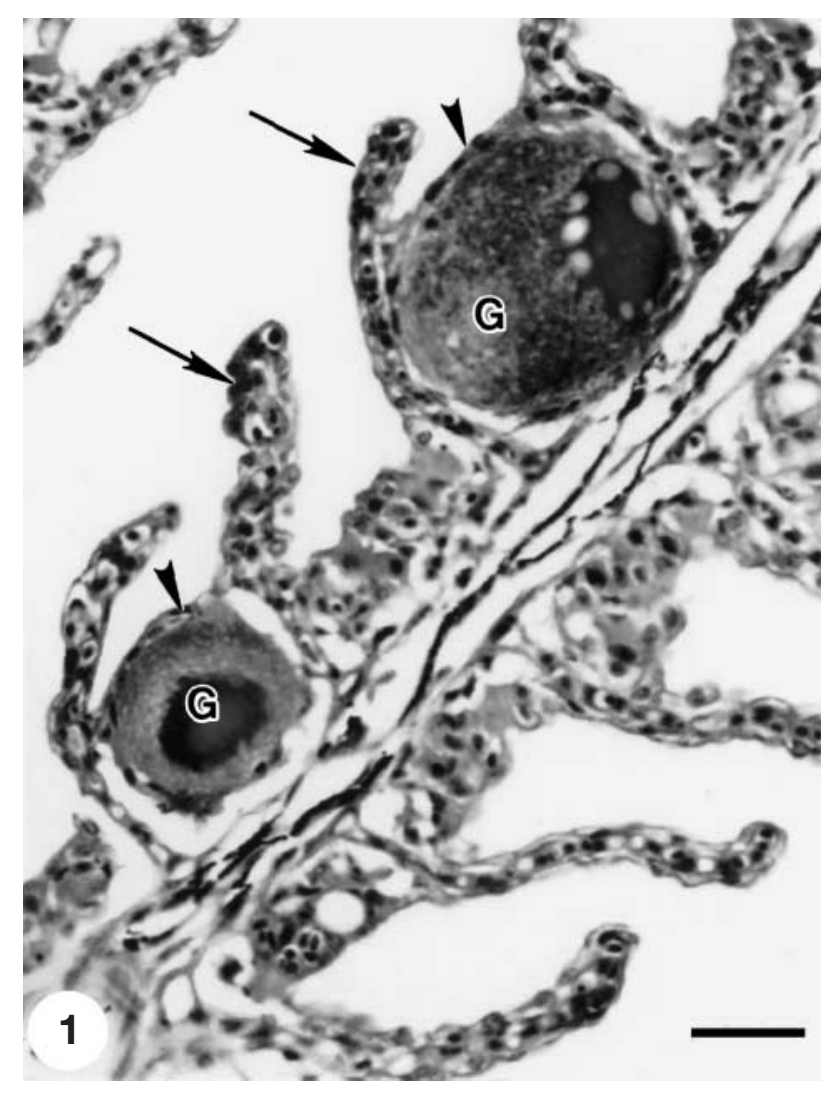

Fig. 1. Scophthalmus maximus. Giant cells (G) in turbot gills located between secondary lamellae (arrows) and covered by 1 to 2 layers of squamous respiratory epithelium (arrowhead). Scale bar $=20 \mu \mathrm{m}$ 
division was missing, and the cell contents appeared to be homogenous. Occasionally, large vacuoles were observed at the periphery of the nucleus (Fig. 1). These vacuoles either appeared empty, or had a homogenous eosinophilic content. In the gills, giant cells usually occurred singly, situated at the base of and between secondary lamellae (Fig. 1). In the epidermis, giant cells usually occurred singly or in small groups of 2 or 3 cells, often surrounded by a thin, concentric layer of elongated epithelial cells (Fig 2). Occasional foci of necrotic cells were detected in the epidermis, but there was little evidence of a subsequent cellular response to the virus infection.

\section{Transmission electron microscopy results}

Electron microscopy of giant cells showed numerous enveloped particles in electron-dense regions, as well as in loosely granulated material surrounding the more dense regions. In cells with a distinct nuclear membrane, the enveloped particles were confined to the cytoplasm, but in some cells a distinction between the nucleus and the cytoplasm was missing. Typical parti-

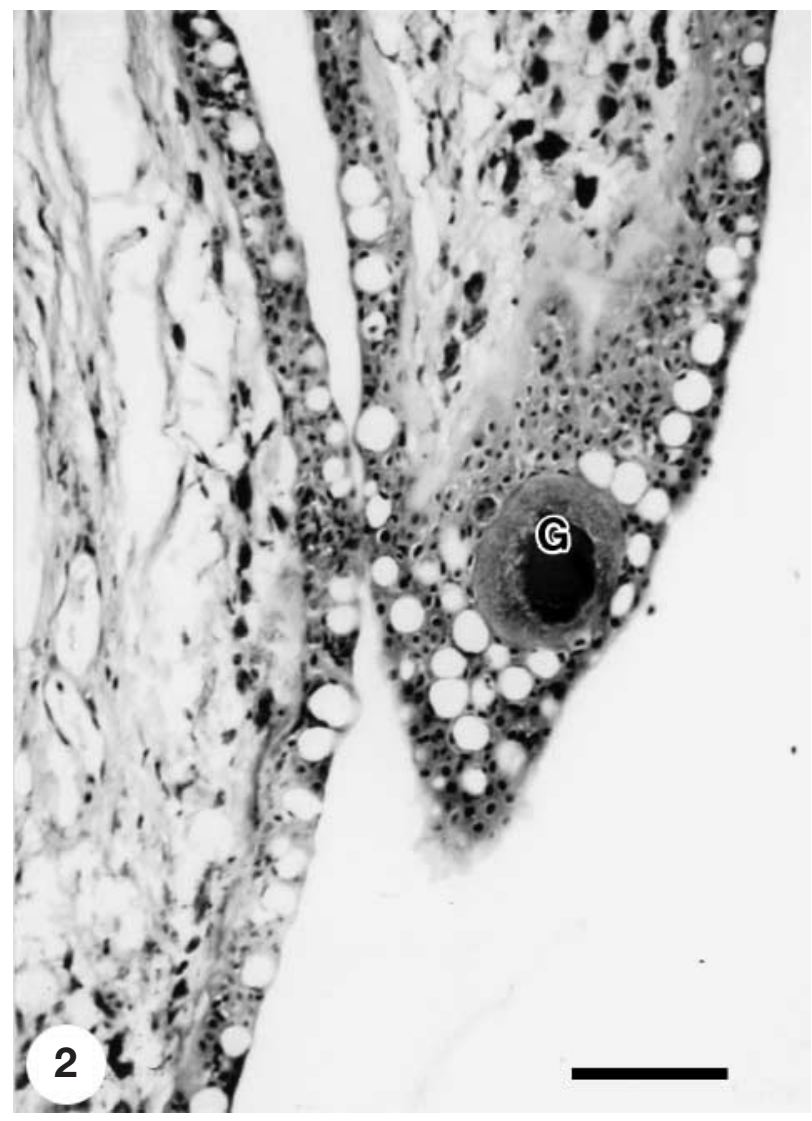

Fig. 2. Scophthalmus maximus. Giant cell (G) in turbot skin. A giant cell is observed in the epidermis. Scale bar $=50 \mu \mathrm{m}$ cles could be defined as containing 5 zones consisting of (1) spikes in the range of $20 \mathrm{~nm}$, (2) a trilaminar membrane, (3) an electron-translucent layer, (4) an electron-dense capsid with a diameter of about $100 \mathrm{~nm}$, (5) and a translucent space around the core of 25 to $30 \mathrm{~nm}$ (Fig. 3). The total diameter was approximately 200 to $220 \mathrm{~nm}$. In some particles, the core was missing, especially in particles confined to the electron-dense regions of the cytoplasm. In giant cells containing a distinct nuclear structure, unenveloped virus particles were located within the nucleus, and enveloped particles on the exterior of the nuclear membrane (Fig. 4). An overview micrograph of an infected cell lacking the nucleus shows how the particles are released through the cytoplasmic membrane into the water (Fig. 5).

\section{DISCUSSION}

The structure of the present particles is identical to that previously described for Herpesvirus scophthalmi virions (Buchanan \& Madely 1978, Buchanan et al. 1978, Bloch \& Larsen 1994). In addition to the localization of the particles to giant cells in the epidermis and

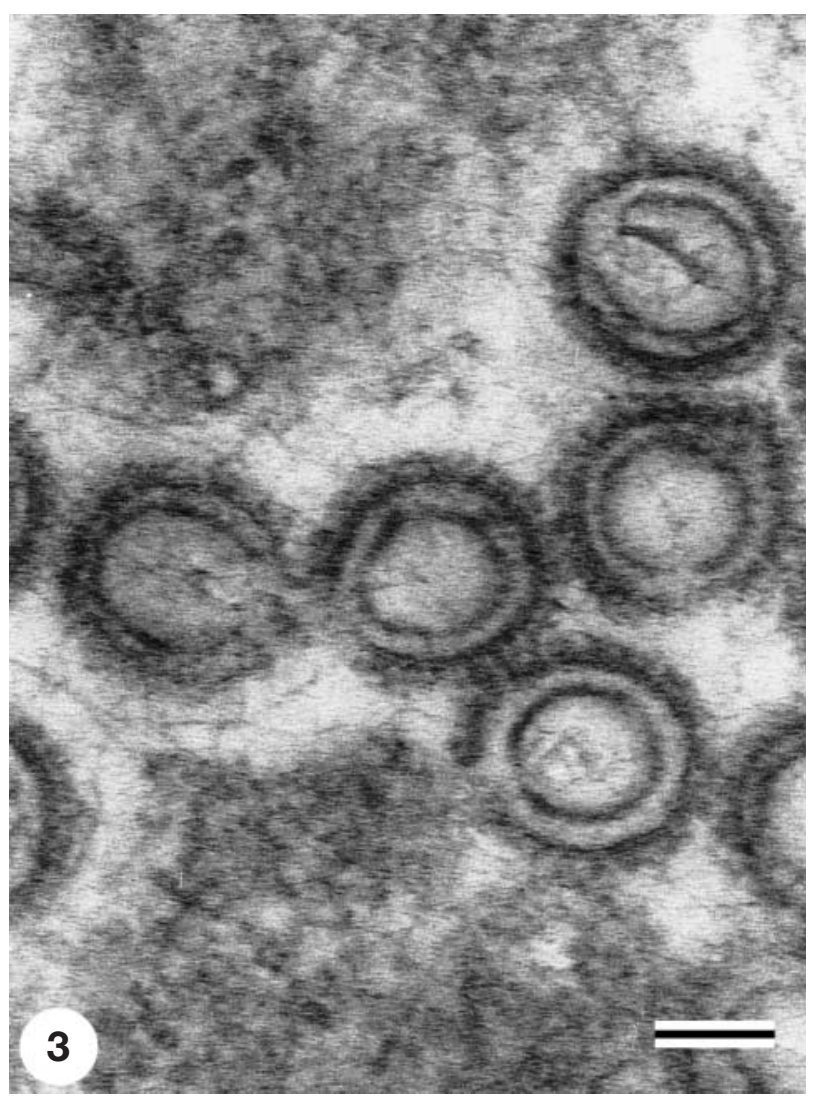

Fig. 3. Scophthalmus maximus. Electron micrograph of giant cell in turbot with enveloped virus particles in the cytoplasm. Scale bar $=100 \mathrm{~nm}$ 


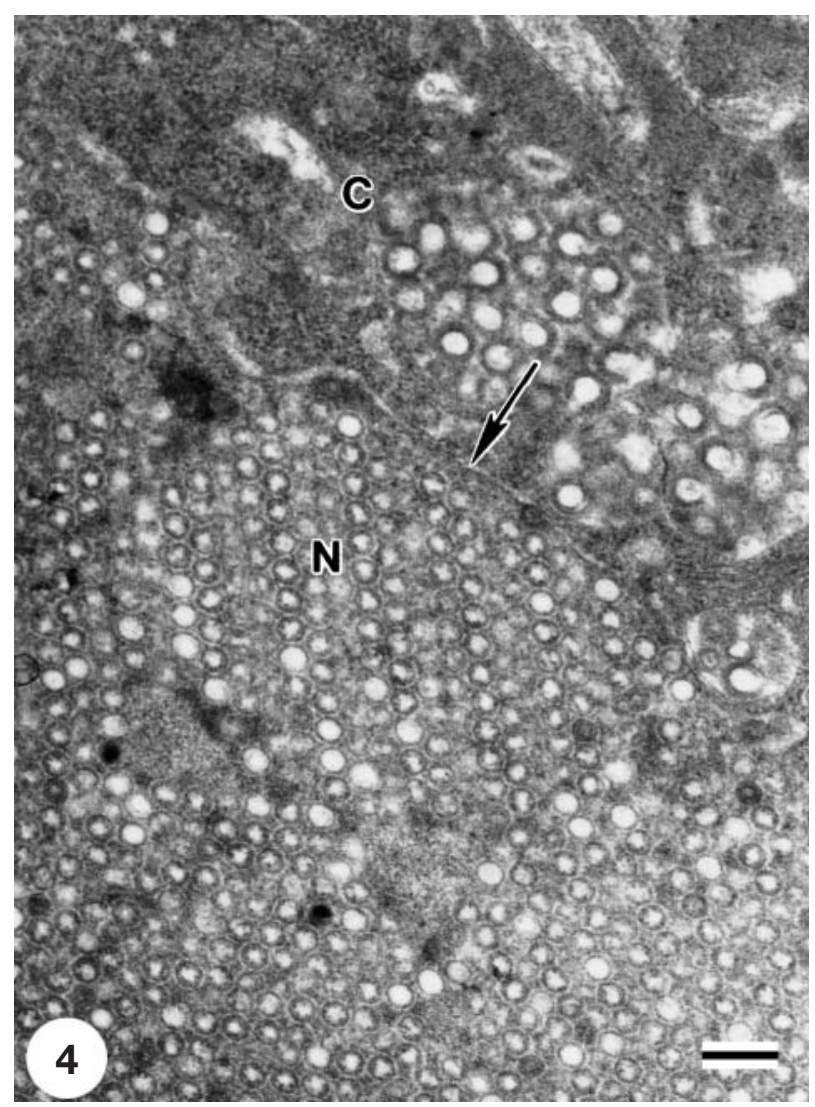

Fig. 4. Scophthalmus maximus. Electron micrograph of a giant cell in turbot showing virus particles in nucleus $(\mathrm{N})$ and cytoplasm (C). Naked particles occur in the nucleus and enveloped particles in the cytoplasm. Nuclear membrane (arrow). Scale bar $=300 \mathrm{~nm}$

gill epithelium in turbot, and the observation of enveloped particles in the cytoplasm and unenveloped particles in the nucleus in these cells, this strongly indicates that the virus we observed is similar or identical to that previously reported. This is the first demonstration of herpesvirus infection in farmed turbot in Norway.

The Norwegian production of turbot is limited, and the 2 existing hatcheries have been included in the screening programme. Screening of turbot for the turbot herpesvirus started in 1999, and the results have been negative so far, except for the present findings in imported turbot. Turbot farming is increasing, and unless the Norwegian production of turbot larvae increases, further imports must be expected.

There is little information available on the distribution and prevalence of the herpesvirus in different turbot populations. There have been no reports of problems associated with the turbot herpesvirus in France, a possible potential source of the infection. In the present investigation, 26 out of 28 randomly selected fish

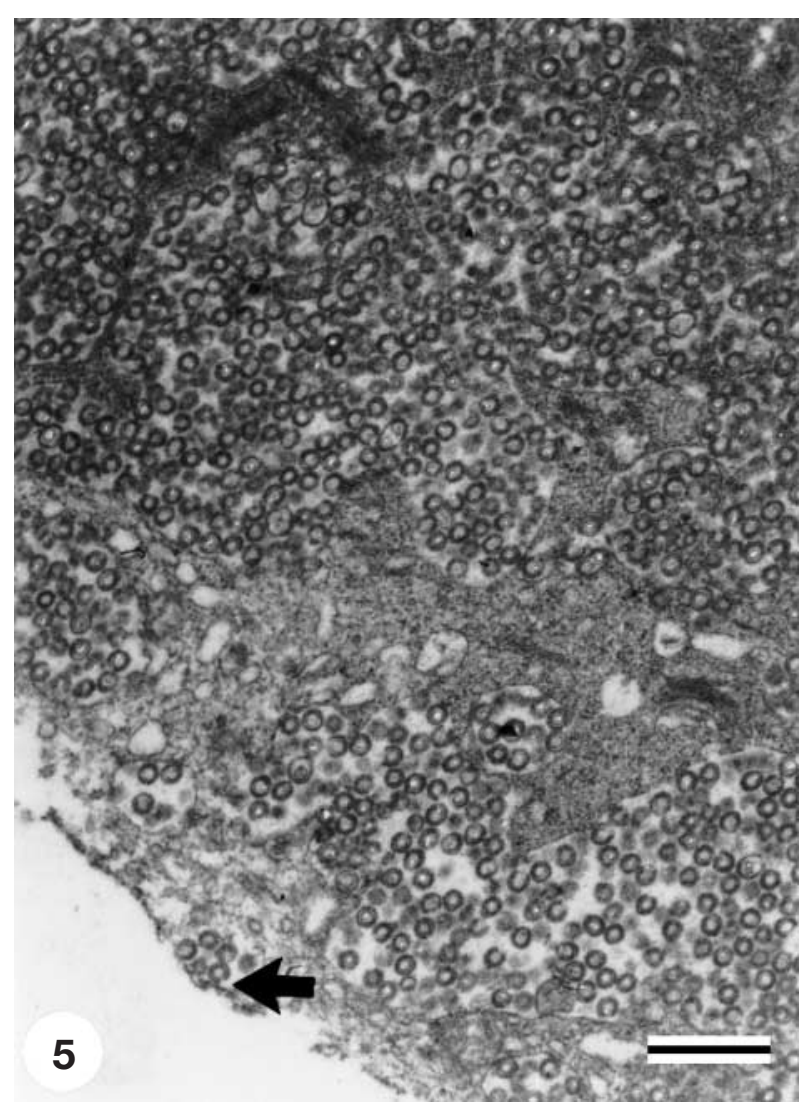

Fig. 5. Scophthalmus maximus. Electron micrograph of a giant cell in turbot showing virion release into the water (arrow) from a gill giant cell without a nucleus. Scale bar $=1 \mu \mathrm{m}$

were positive in the first sampling and 15 out of 30 in the second sampling, indicating a high prevalence of positive individuals in the population. Sampling from a later importation (in 2001) showed 7 positive of 31 individuals at the first sampling and 9 out of 29 individuals at the second. Buchanan \& Madely (1978) and Bloch \& Larsen (1994) assumed that the virus was endemic in the wild population and that clinical signs only appeared in particularly stressed individuals. In our material, the morphological manifestations were detected as a result of a screening programme, and increased mortality or apparent changes in behaviour were not observed. This distinguishes our material from previously described cases, where clinical signs have led to the investigations. In the present case, the fish had been subjected to some stress due to transportation, and it is possible that this provoked a subclinical manifestation of the disease. The frequency of affected cells in the present samples was not high, and the situation may approach that described by Richards \& Buchanan (1978), where fewer giant cells were observed in fish without clinical signs from an affected stock. 
Today, infection with the turbot herpesvirus is classified as a Group B, i.e. a notifiable disease, according to the regulations given by the Norwegian veterinary authorities, implicating certain measures when being detected. The fish cannot be moved to other locations or brought into contact with fish destined for movement. Also, increased mortality or manifestation of clinical disease may result in destruction. Further importation of turbot larvae and juveniles is not encouraged and other sources must be considered.

The affected population has been closely monitored for more than 6 mo. Increasing mortality and signs of disease have not been observed during this period. This indicates that the presence of giant cells and herpesvirus-like particles may not always be associated with disease.

The distribution and the pathogenicity of the virus deserve further investigation. Efforts will be made to examine the distribution of the turbot herpesvirus, particularly in wild turbot in Norway, which due to the water supply in the raceways, cannot be ruled out as a potential source for the observed infection. However, the high prevalence of giant cells in fish sampled only $5 \mathrm{~d}$ after importation indicates that the fish had been infected before arrival in Norway.

Editorial responsibility: Jo-Ann Leong,

Corvallis, Oregon, USA

\section{LITERATURE CITED}

Bancroft JB, Stevens A (1990) Theory and practice of histological techniques. Churchill Livingstone, London

Bloch B, Larsen JL (1994) A case of severe general oedema in young farmed turbot associated with a herpes virus infection. Bull Eur Assoc Fish Pathol 14:130-132

Buchanan JS, Madely CR (1978) Studies on Herpesvirus scophthalmi infection of turbot Scophthalmus maximus (L.) ultrastructural observations. J Fish Dis 1:283-295

Buchanan JS, Richards RH, Sommerville C, Madely CR (1978) A herpes-type virus from turbot (Scophthalmus maximus L). Vet Rec 102:527-528

Håstein, T (1999) Herpesvirusinfeksjoner. In: Poppe TT (ed) Fiskehelse og fiskesykdommer. Universitetsforlaget, Oslo, p 160-164 (in Norwegian)

Hedrick RP, Sano T (1989) Herpesvirus of fishes. In: Ahne W, Kurstak E (eds) Viruses of lower vertebrates. SpringerVerlag, Berlin, p 161-170

Hetrick FM, Hedrick RP (1993) New virus described in finfish from 1988-1992. Annu Rev Fish Dis 3:187-207

Richards RH, Buchanan JS (1978) Studies on Herpesvirus scophthalmi infection of turbot Scophthalmus maximus (L.): histopathological observations. J Fish Dis 1:251-258

Roizman B (1982) The family Herpesviridae. General description, taxonomy, and classification. In: Roizman B (ed) The viruses, Vol.1. Herpesviruses. Plenum Press, New York, p 1-23

Wolf K (1988) Fish viruses and fish viral diseases. Comstock Publishing Associates, Cornell University Press, Ithaca, NY

Submitted: July 28, 2001; Accepted: October 13, 2001

Proofs received from author(s): April 10, 2002 